\title{
Influence of agro-technical measures on chlorophyll activity of soybean plants
}

\author{
Malinovska I. ${ }^{1}$, Borko Yu. ${ }^{2}$ \\ NSC «Institute of Agriculture of NAAS» \\ 2b Mashynobudivnykiv Str., vil. Chabany, Fastiv region, Kyiv oblast, 08162, Ukraine

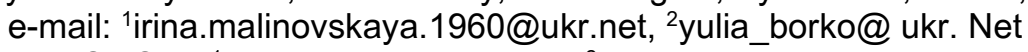 \\ ORCID: ${ }^{1} 0000-0001-5945-2042,{ }^{2} 0000-0002-6277-8980$
}

\begin{abstract}
Goal. To study the laws of functioning of the photosynthetic apparatus of soybean plants under different elements of culture technology. Methods. The experimental field method was used for growing soybean plants of the Siverka variety using advanced technologies, the laboratory-analytical method was used to determine the characteristics of the photosynthetic apparatus of soybean plants, and the statistical method was used to calculate statistical deviations from the mean value. Results. The higher activity of chlorophyll and enzymes of the Calvin cycle in the bean filling phase was observed in soybean plants in the variant with the application of mineral fertilizers in doses of N100P60K100 and N40P40K60 on the background of plowing of exogenous organic matter. Increasing the dose of mineral fertilizers increased the activity of chlorophyll by $56.0 \%$, the activity of enzymes of the Calvin cycle - by $53.1 \%$. With the plowing of by-products on the background of mineral fertilizers, the activity of chlorophyll increased by $33.3 \%$. In the phase of full maturity, the maximum activity of chlorophyll and enzymes of the Calvin cycle was characterized by plants in variants with the application of mineral fertilizers at a dose of N40P40K60 and control (without fertilizers) without plowing byproducts of the predecessor in crop rotation. The variant with the maximum dose of fertilizers and high activity of chlorophyll and enzymes of the Calvin cycle during the growing season in the phase of full maturity had the lowest indices among the studied variants. Increasing the dose of fertilizers led to a decrease in the activity of chlorophyll by $48.7 \%$, the activity of Calvin cycle enzymes - by $36.2 \%$. Conclusions. The use of the method of induction of chlorophyll fluorescence allows to objectively assess the physiological state of soybean plants during the growing season and to take into account the significance of the influence of exogenous and endogenous factors.
\end{abstract}

Key words: fluorescence, photosynthesis, leaves, functional state, physiological processes, Calvin cycle. DOI: https://doi.org/10.31073/agrovisnyk202102-03

Natural and climatic conditions of the forest-steppe zone of Ukraine are generally favorable for growing crops, but the instability of yields and gross harvests of agricultural products hinder the introduction and expansion of sown areas. For the effective use of the bioclimatic potential of the soil-climatic zone and the features of modern varieties of crops, it is important to deepen the study of physiological processes of plant organisms with the application of various agricultural measures [1]. In particular, with the introduction of the latest technologies for growing crops, obtaining objective information on the state of crops will allow for scientifically sound management of the production process, taking into account the real needs of the plant [24].

The application of intensive technologies in crop production, development, and implementation of scienceintensive methods of precision agriculture requires the use of various automated systems for monitoring the agricultural land condition. It allows you to assess the condition of vegetation quickly. One of the modern methods of obtaining data on the state and physiological processes in plants is the method of induction of plant chlorophyll fluorescence in the red spectrum of light $[5,6]$. Photosynthesis is a key part of the complex process of ontogenesis, which provides the overall growth and development of plants following their genetic characteristics. In the process of photosynthesis, there is a conversion of light energy, assimilation of carbon compounds through biochemical energy bonds of photosynthesis products.

At different levels of photosynthetically active radiation (PAR), temperatures and the influence of external factors, including stressors, the state of the photosynthetic apparatus, and the productivity of photosynthesis are changed in plants. An indicator of such physiological changes is chlorophyll. It localized in photosynthetic membranes and has certain spectral properties, changes in which can be detected and recorded in real-time. It is on this basis that the necessary information for rapid diagnosis of cell status is obtained [6-8]. Thus, the study of physiological processes of plants to develop and scientifically substantiate measures aimed at increasing yields and improving their quality, are relevant.

The research purpose is to study the patterns of functioning of the soybean plants photosynthetic apparatus under different elements of cultivation technology.

The research object is the changes in the chlorophyll activity depending on the agricultural measures used in the intensive technology of soybean cultivation.

Materials and research methods. The research was conducted in a stationary experiment of the Department of Intensive Technologies of Cereals and Maize "Development and improvement of technologies 
for growing cereals based on expanded soil fertility reproduction" NSC "Institute of Agriculture NAAS" in 20142015. The fertilizer system included: option 1 is an application of mineral fertilizers at a dose of $\mathrm{N}_{20} \mathrm{P}_{30} \mathrm{~K}_{30} ; 2$ $\mathrm{N}_{40} \mathrm{P}_{60} \mathrm{~K}_{60} ; 3-\mathrm{N}_{100} \mathrm{P}_{60} \mathrm{~K}_{100} ; 5-\mathrm{N}_{60} \mathrm{P}_{90} \mathrm{~K}_{90} ; 6-\mathrm{N}_{40} \mathrm{P}_{40} \mathrm{~K}_{60} ; 10$ - control (without fertilizers); the scheme of variants of the experiment №1-10 provides for plowing of by-products of the predecessor in crop rotation (PP); 11 $\mathrm{N}_{40} \mathrm{P}_{40} \mathrm{~K}_{60}$ without PP; 12 - control (without fertilizers) without PP. In the experiment, soybean cultivar Siverka was grown, the predecessor was winter grain. The area of the sown area is $60 \mathrm{~m}^{2}$, the accounting area is 24.0 $\mathrm{m}^{2}$. Repetition - four times. The soil of the experimental site is dark gray podzolic coarse-grained light loam on loess-like loam with a humus content of 1.46-1.96 \% (according to Tyurin); easily hydrolyzed nitrogen - 61-94 $\mathrm{mg} / \mathrm{kg}$ of soil (according to Cornfield); mobile phosphorus and exchangeable potassium (according to Chirikov) - respectively $89-225$ and $105-188 \mathrm{mg} / \mathrm{kg}$ of soil; $\mathrm{pH}-5.2-5.5$. The tillage system is generally accepted for the study area and included $20-22 \mathrm{~cm}$ of fallow plowing under soybeans, early spring moisture closure, and presowing cultivation. Amophos (52\% a.s. $\left.\mathrm{P}_{2} \mathrm{O}_{5}\right)$ and potassium salt $\left(60 \%\right.$ a.s. $\left.\mathrm{K}_{2} \mathrm{O}\right)$ were applied under the main tillage, ammonium nitrate (34.4\% a.s. N) - under pre-sowing cultivation.

The method of induction of chlorophyll fluorescence (ICF) is used to study the functional characteristics of the photosynthetic apparatus of soybean plants. It is a registration of chlorophyll fluorescence of leaves, the kinetics of which has a characteristic curve (Kautsky curve) and reflects the parameters of primary processes of photosynthesis [6-8]. The energy of absorbed quanta light not used in photosynthesis is converted into either heat or chlorophyll fluorescence. Fluorescence parameters are an indicator of the state and efficiency of photosynthesis. The determination conducted using a single-beam fluorometer "Floratest" at 3-minute mode. Statistical processing and mathematical analysis of research results conducted using MS Excel 10.0 and STATISTICA 7.0.

Research results and their discussion. Scientific researches of domestic and foreign scientists testify to the possibility of using the effect of chlorophyll fluorescence induction for express assessment of plant life under the influence of biotic and abiotic factors - drought, frost, pesticide application, determination of optimal doses of mineral fertilizers, environmental pollution. It makes it possible to automate research in the industry of crop production, to determine the optimal doses of trace elements, fertilizers, growth stimulants, etc. [9-10].

It have been established that the activity of chlorophyll of soybean leaves of the Siverka variety are changed during the growing season as a result of the conducted researches. It fluctuates around 2293 relative units at the end of the flowering phase, 1204 - in the filling beans phase, 243 relative units - in the full ripeness phase. The maximum activity of chlorophyll and enzymes of the Calvin cycle in the bean filling phase is characterized the soybean plants with the application of mineral fertilizers at a dose of $\mathrm{N}_{100} \mathrm{P}_{60} \mathrm{~K}_{100}$ and $\mathrm{N}_{40} \mathrm{P}_{40} \mathrm{~K}_{60}$ against the background of plowing exogenous organic matter (Fig. 1-3).

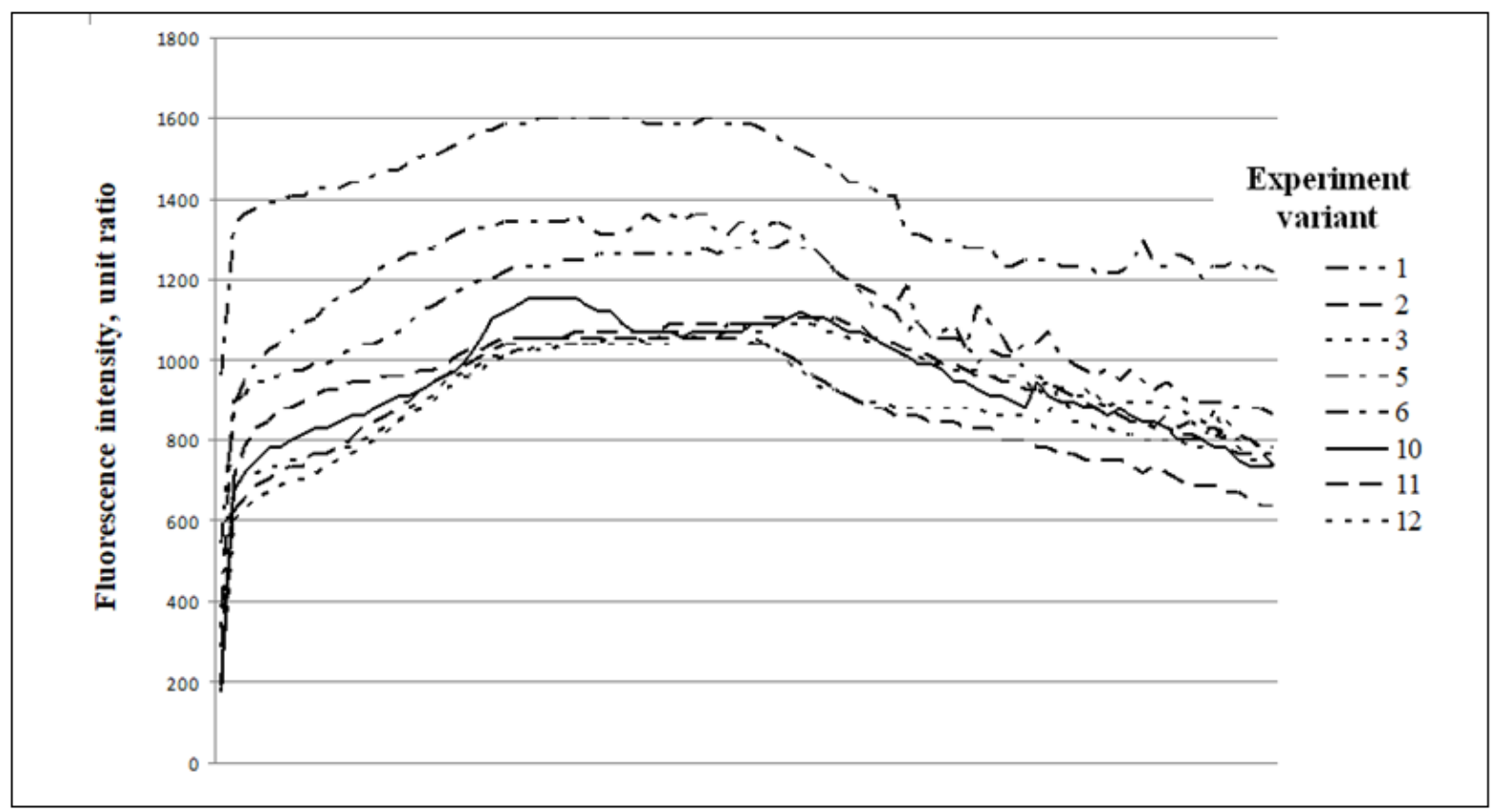

Fig. 1. Induction of chlorophyll fluorescence change of soybean leaves of Siverka variety in the bean filling phase under the influence of by-products plowing of crop production and mineral fertilizers application in doses: 1 - $N_{20} P_{30} K_{30}, 2-N_{40} P_{60} K_{60}, 3-N_{100} P_{60} K_{100}, 5-N_{60} P_{40} K_{90}, 6$ - fertilizers, $11-N_{40} P_{40} K_{60}, 12$ - without fertilizers (also for figures № 2-5) 


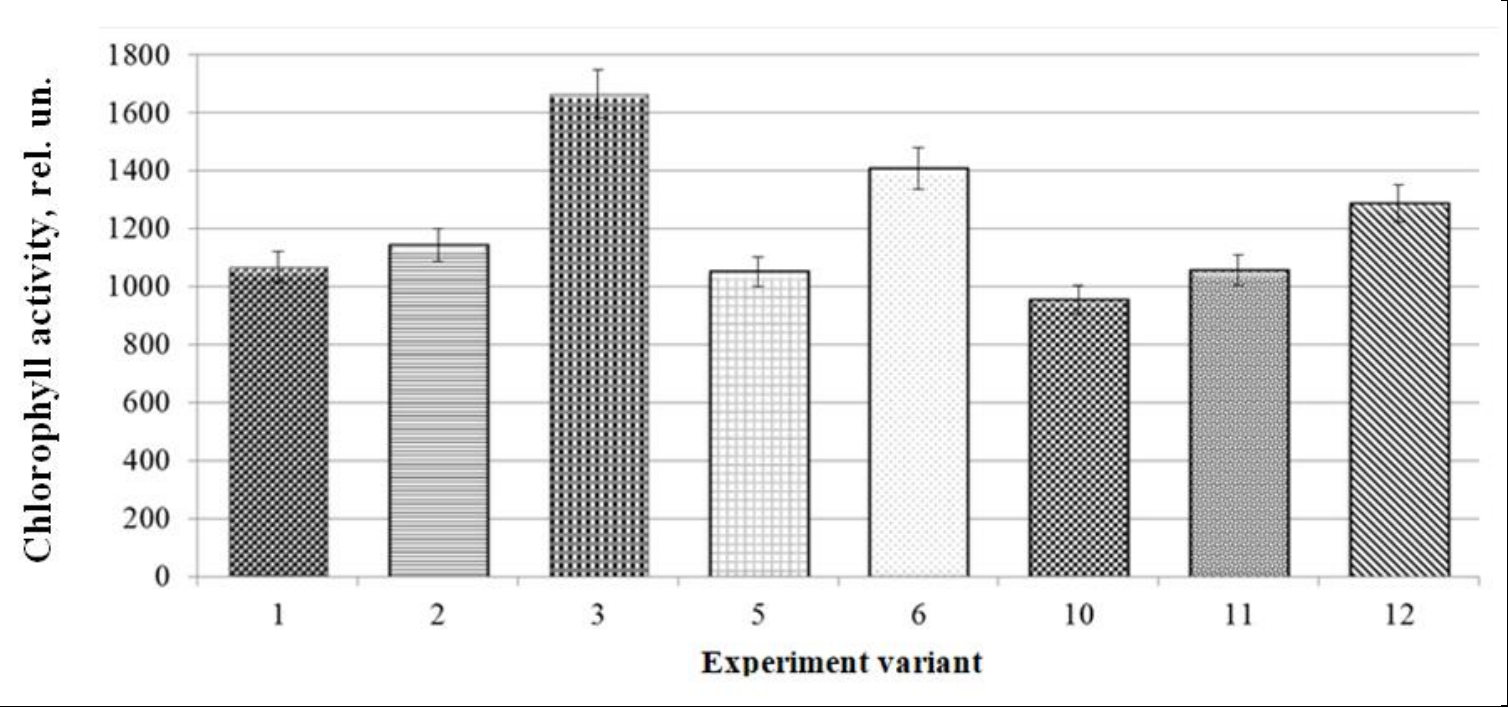

Fig. 2. Chlorophyll activity of soybean leaves of Siverka variety in the bean filling phase under the influence of by-products plowing of crop production and application of mineral fertilizers in different doses

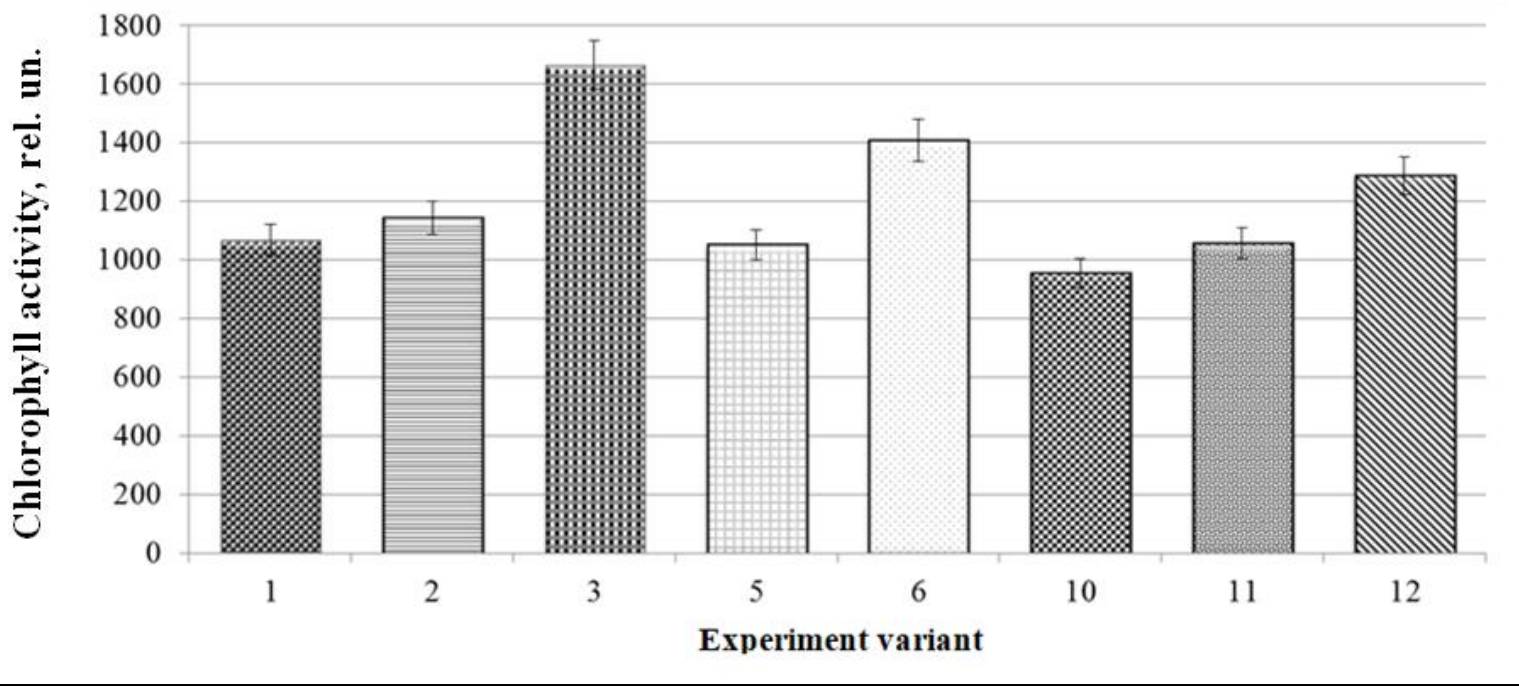

Fig. 3. Activity of the Calvin cycle enzymes of soybean leaves of the Siverka variety in the bean filling phase under the influence of by-products plowing of crop production and mineral fertilizers application in different doses

Increasing the dose of mineral fertilizers increases the activity of chlorophyll by $56.0 \%$, the activity of enzymes of the Calvin cycle - by $53.1 \%$. Plowing of by-products on the background of mineral fertilizers contributes to increasing of chlorophyll activity by 33.3\% (Fig. 2). However, in the variant without fertilizers, the tendency to decrease the chlorophyll activity as a result of plowing of exogenous organic matter compared to the previous phase of plant development increases (by 35.0\%). The enzymes activity of the Calvin cycle changes in a similar way. Plowing of by-products against the background of mineral fertilizers leads to activation of enzymes, and against the background without fertilizers is to inactivation of enzymes (Fig. 3).

There are separated options without fertilizers (with plowing by-products and without), as well as with a minimum dose of mineral fertilizers according to the indicators of exogenous factors influence in the filling beans phase as well as in the phase of flowering - the beans formation (Table 1). 
1. Indicators of the state of photosynthesis apparatus of soybean plants of the Siverka variety in the bean filling phase under the influence of agrotechnical measures in the conditions of the field experiment

\begin{tabular}{|c|c|c|c|c|c|}
\hline № & \multicolumn{2}{|c|}{ Variant } & $\begin{array}{l}\text { Indicator of exogenous } \\
\text { factors influence, } \%\end{array}$ & $\begin{array}{c}\text { Indicator of } \\
\text { fluorescence quantum } \\
\text { yield, \% }\end{array}$ & $\begin{array}{l}\text { Indicator of } \\
\text { endogenous } \\
\text { factors, \% }\end{array}$ \\
\hline 1 & $\mathrm{~N}_{20} \mathrm{P}_{30} \mathrm{~K}_{30}$ & \multirow{6}{*}{ 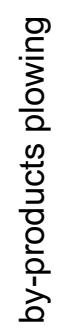 } & 35,7 & 38,3 & 27,7 \\
\hline 2 & $\mathrm{~N}_{40} \mathrm{P}{ }_{60} \mathrm{~K}_{60}$ & & 21,8 & 21,5 & 36,0 \\
\hline 3 & $\mathrm{~N}_{100} \mathrm{P}_{60} \mathrm{~K}_{100}$ & & 28,7 & 25,7 & 37,7 \\
\hline 5 & $\mathrm{~N}_{60} \mathrm{P}_{90} \mathrm{~K}_{90}$ & & 25,0 & 29,3 & 26,7 \\
\hline 6 & $\mathrm{~N}_{40} \mathrm{P}_{40} \mathrm{~K}_{60}$ & & 41,3 & 40,0 & 58,0 \\
\hline 10 & - & & 31,0 & 34,3 & 38,7 \\
\hline 11 & \multicolumn{2}{|c|}{$\mathrm{N}_{40} \mathrm{P}_{40} \mathrm{~K}_{60}$} & 33,7 & 39,7 & 75,7 \\
\hline 12 & \multicolumn{2}{|l|}{ - } & 28,3 & 33,8 & 29,0 \\
\hline
\end{tabular}

The increase of mineral fertilizers dose is caused by a decrease of exogenous factors that influence the state of the photosynthetic apparatus from 35.7 to 21.8 and $28.7 \%$. Conversely, the optimization of plants mineral nutrition is accompanied by an increase in the role of endogenous factors from 27.7 to $37.7 \%$. Byproducts plowing of the predecessor is contributed to the increase of the exogenous factors influence on the photosynthetic apparatus of soybean plants, both against the background of mineral fertilizers and without them. A similar dependence is observed for endogenous factors on the background without fertilizers, and for the application of mineral fertilizers - the opposite: there is a decrease in the sensitivity of the photosynthetic apparatus to endogenous factors. The values of both exogenous and endogenous factors decrease by about 2.0 times compared with the previous phase of plant development (Table 1,2).

2. Indicators of the state of photosynthesis apparatus of soybean plants of Siverka variety in the full maturity phase under the agrotechnical measures influence in the conditions of field experiment

\begin{tabular}{|c|c|c|c|c|c|}
\hline № & \multicolumn{2}{|c|}{ Variant } & $\begin{array}{l}\text { Indicator of exogenous } \\
\text { factors influence, } \%\end{array}$ & $\begin{array}{c}\text { Indicator of } \\
\text { fluorescence quantum } \\
\text { vield } \%\end{array}$ & $\begin{array}{l}\text { Indicator of } \\
\text { endogenous }\end{array}$ \\
\hline 1 & $\mathrm{~N}_{20} \mathrm{P}_{30} \mathrm{~K}_{30}$ & \multirow{6}{*}{ 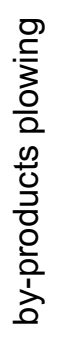 } & 8,0 & 4,7 & 54,3 \\
\hline 2 & $\mathrm{~N}_{40} \mathrm{P}{ }_{60} \mathrm{~K}_{60}$ & & 13,7 & 4,0 & 45,7 \\
\hline 3 & $\mathrm{~N}_{100} \mathrm{P}_{60} \mathrm{~K}_{100}$ & & 3,7 & 2,0 & 36,0 \\
\hline 5 & $\mathrm{~N}_{60} \mathrm{P}_{90} \mathrm{~K}_{90}$ & & 10,0 & 5,3 & 25,0 \\
\hline 6 & $\mathrm{~N}_{40} \mathrm{P}_{40} \mathrm{~K}_{60}$ & & 41,3 & 40,0 & 58,0 \\
\hline 10 & - & & 3,7 & 0,0 & 21,7 \\
\hline 11 & \multicolumn{2}{|c|}{$\mathrm{N}_{40} \mathrm{P}_{40} \mathrm{~K}_{60}$} & 8,7 & 6,7 & 55,0 \\
\hline 12 & \multicolumn{2}{|l|}{ - } & 8,3 & 1,0 & 31,0 \\
\hline
\end{tabular}

The maximum activity of chlorophyll and enzymes of the Calvin cycle in the full maturity phase is characterized the plants with mineral fertilizers application at a dose of $\mathrm{N}_{40} \mathrm{R}_{40} \mathrm{~K}_{60}$ (var. №6) and control without fertilizers and without by-products plowing of the predecessor in crop rotation (var. №12) (Fig. 4,5). The variant with the maximum fertilizers dose (№3), which is characterized by high activity of chlorophyll and Calvin cycle enzymes during the growing season, in the full maturity phase have showed the lowest indexes among the studied variants. Increasing the fertilizers dose in full maturity phase leads to a decrease in the chlorophyll activity by $48.7 \%$, the activity of the Calvin cycle enzymes - by $36.2 \%$.

By-products plowing, depending on the background, has a different effect on both studied indicators: against the background of mineral fertilizers, the application of exogenous substances activates chlorophyll by $52.3 \%$, Calvin cycle enzymes - by $111.0 \%$; against the background without fertilizers, the introduction of exogenous organic matter causes a decrease in the activity of chlorophyll and enzymes of the Calvin cycle by 60.4 and $66.7 \%$, respectively. 


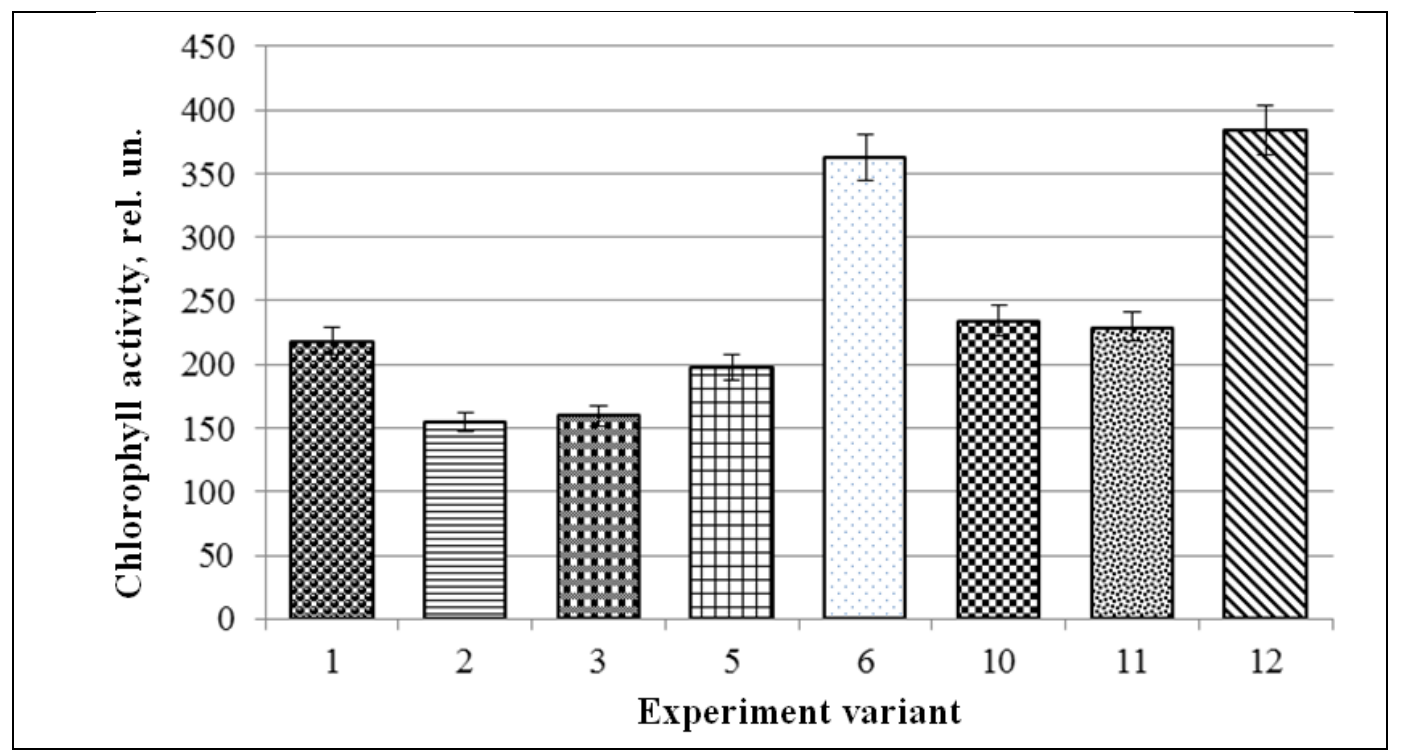

Fig. 4. Chlorophyll activity of soybean leaves of Siverka variety in the full ripeness phase under the influence of by-products plowing of crop production and mineral fertilizers application in different doses

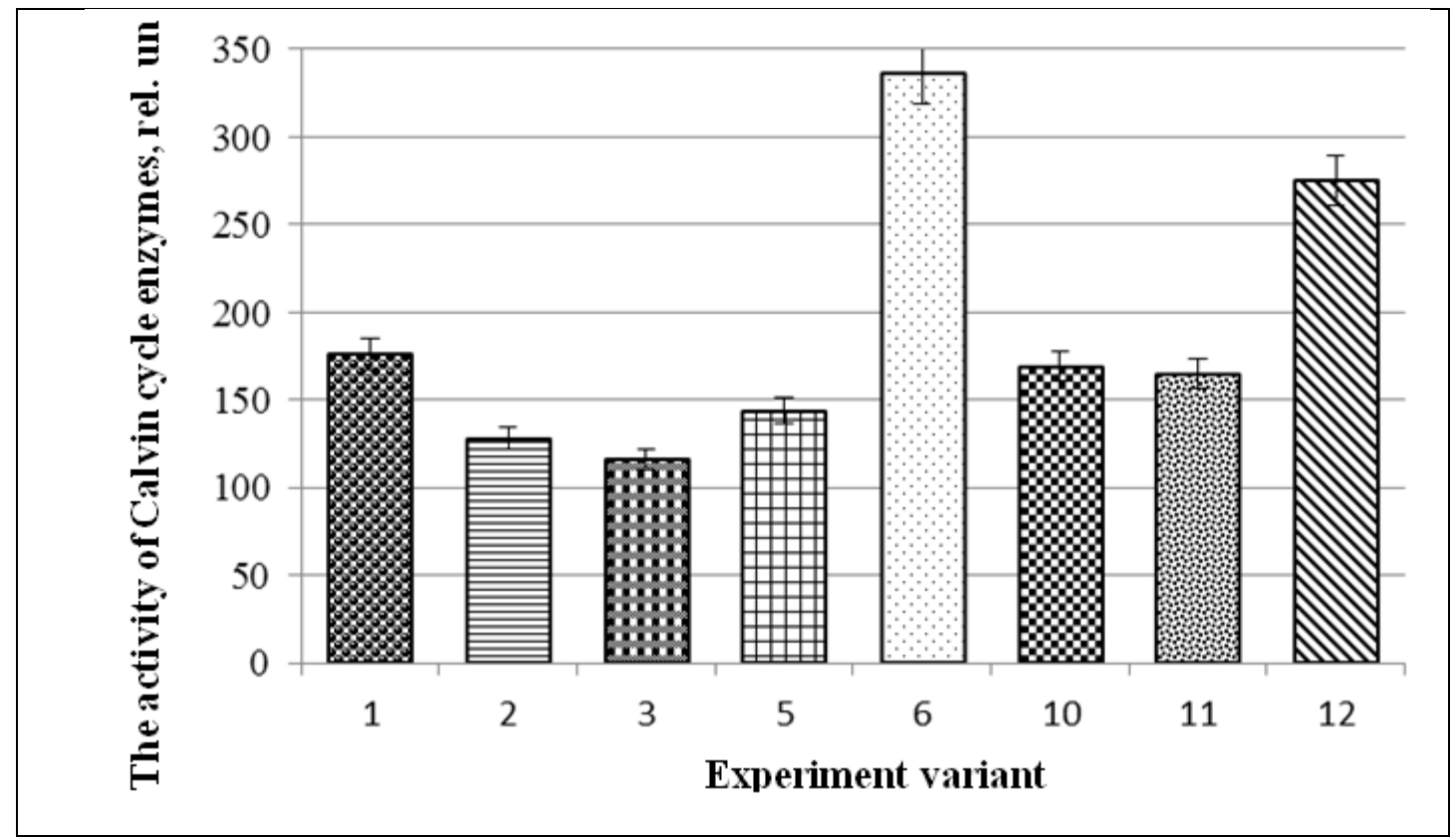

Fig. 5. Activity of the Calvin cycle enzymes of soybean leaves of the Siverka variety in the full maturity phase under the influence of by-products plowing of crop production and mineral fertilizers application in different doses

\section{Conclusions}

Soybean plants with the mineral fertilizers application at a dose of $N_{100} P_{60} K_{100}$ and $N_{40} P_{40} K_{60}$ is characterized by the maximum activity of chlorophyll and the Calvin cycle enzymes in the bean filling phase.

Plants of the variant with mineral fertilizers in the dose $N_{40} R_{40} K_{60}$ and the variant without fertilizers and without by-products plowing of the predecessor in crop rotation is characterized by the highest activity of chlorophyll and the Calvin cycle enzymes in the full maturity phase.

The parameters of chlorophyll fluorescence kinetics are very informative for assessing the state of the primary processes of plant photosynthesis in real-time are experimentally proved. The main parameters of the induction curve can be used as test indicators to determine the resistance of plants to adverse factors of manmade edaphotopes. Changes in these indicators characterize the processes associated with the environment influence on the course of both light and dark phases of photosynthetic processes in chloroplasts. The use of the method of chlorophyll fluorescence induction allows objectively assessing the physiological state of soybean plants during the growing season and taking into account the importance of the influence of exogenous and endogenous factors. 


\section{References}

1. Temrienko, O.O. (2018). Fotosyntetychna ta nasinnieva produktyvnist posiviv soi zalezhno vid tekhnolohichnykh pryiomiv vyroshchuvannia v umovakh Lisostepu Pravoberezhnoho [Photosynthetic and seed productivity of soybean crops depending on technological methods of cultivation in the conditions of the Forest-Steppe of the Right Bank]. Taurian Scientific Bulletin: scientific journal. 2 (100), 75-85. [In Ukrainian].

2. Kalenskaya, S.M., Novitskaya, N.V., \& Dzhemesyuk, O.V. (2016). Formuvannia ploshchi lystkovoi poverkhni soi pid vplyvom inokuliatsii ta pidzhyvlennia [Formation of soybean leaf surface area under the influence of inoculation and fertilization]. Bulletin of the Poltava State Academy. 3, 6-10. [In Ukrainian].

3. Bilinskaya, V.I. (2015). Suchasni innovatsiini tekhnolohii $v$ silskomu hospodarstvi: osnovna kharakterystyka ta perspektyvy vprovadzhennia [Modern innovative technologies in agriculture: main characteristics and prospects of implementation]. Bulletin of Kyiv National University. 7 (172), 74-80. [In Ukrainian].

4. Korsun, S.G., Grusha, V.V., \& Dovbash, N.T. (2015). Induktsiia fluorestsentsii khlorofilu v lystkakh kukurudzy za umov zabrudnennia vazhkymy metalamy. [Induction of chlorophyll fluorescence in corn leaves under conditions of heavy metal contamination]. Agroecological journal. 2, 36-41. [In Ukrainian].

5. Brion, O.V., Korneev, D.Yu. \& Kitaev, O.I. (2000). Instrumentalne vyvchennia fotosyntetychnoho aparatu za dopomohoiu induktsii fliuorestsentsii khlorofilu. Metodychni vkazivky dlia studentiv biolohichnoho fakultetu [Instrumental implantation of photosynthetic apparatus for additional fluorescence induction chlorophyll. Methodical instructions for students of the biological faculty]. Kyiv. [In Ukrainian].

6. Korneev, D.Yu. (2002). Informatsionnyie vozmozhnosti metoda induktsii fluorestsentsii hlorofilla [Informational capabilities of the chlorophyll fluorescence induction method]. Kyiv. [In Russian].

7. Lakovich, D. (1968). Osnovyi fluorestsentnoy spektroskopii [Fundamentals of fluorescence spectroscopy]. Moscow. [In Russian].

8. Butler, W.L. (1977). Chlorophyll fluorescence: a probe for electron transfer and energy transfer. Encyclopedia of Plant Physiology, 5, 149-167.

9. Muller, N.J.C. (1874). Beziehungen zwischen Assimilation, Absorption und Fluoreszenz im Chlorophyll des lebenden Blattes. Jahrbucher Wissenchaftliche Botanik, 9, 42-49.

10. Strasser, R., Tsimilli-Michael, M., \& Srivastava, A. (2004). Analysis of the Chlorophyll a Fluorescence Transient. Chlorophyll fluorescence: a signature of photosynthesis. The Netherlands. 